\title{
DOBÓR BADAŃ GEOTECHNICZNYCH NA POTRZEBY ROZPOZNANIA PODŁOŻA WYSOKOŚCIOWCÓW
}

\author{
Mirosław J. Lipiński ${ }^{\bowtie}$, Małgorzata K. Wdowska \\ Wydział Budownictwa i Inżynierii Środowiska, Szkoła Główna Gospodarstwa Wiejskiego w Warszawie
}

\begin{abstract}
STRESZCZENIE
Rozpoznanie warunków geotechnicznych na potrzeby posadowienia wysokich budynków wymaga odpowiedniego doboru metod badań, istotnie różniących się od metod stosowanych dla obiektów standardowych. W artykule przedstawiono ograniczenia standardowych metod badań geotechnicznych w odniesieniu do rozpoznania podłoża wysokościowców. Podano również formuły określające parametry sztywności mocnych gruntów spoistych i niespoistych, które mogą być wykorzystane na etapie projektowania fundamentu. Wykorzystując przykłady wykonanych badań dla najwyższych budynków wybudowanych w ostatnich latach w Warszawie, przedstawiono możliwości wiarygodnego wyznaczenia parametrów stanu i sztywności niezbędnych dla sprawdzenia stanu granicznego użytkowalności.
\end{abstract}

Słowa kluczowe: wysokościowce, rozpoznanie podłoża, dobór badań geotechnicznych, prędkość fal sejsmicznych, parametry stanu, sztywność gruntu

\section{WSTĘP}

W zdecydowanej większości dużych miast na świecie od drugiej połowy XIX wieku obserwuje się systematyczny wzrost liczby nowo powstałych budynków wysokich. Wynika to z koncentracji podmiotów gospodarczych i finansowych w centrach metropolii. Można nawet zaobserwować zbieżność intensywności rozwoju gospodarczego z liczbą budowanych wysokościowców na przykładzie Stanów Zjednoczonych (z przełomu XIX i XX wieku), Hong Kongu, Dubaju, a nawet Polski po 1989 roku. Tendencji tej nie mogą nawet powstrzymać niekorzystne warunki wynikające z dużej sejsmiczności terenu, jak choćby w przypadku Japonii czy południowo-zachodniego wybrzeża Stanów Zjednoczonych i Meksyku.

Definicje wysokich budynków są różne, w zależności od kraju. W Polsce, według definicji zawartej w prawie budowlanym, budynek wysoki ma więcej niż $25 \mathrm{~m}$ wysokości, natomiast wysokościowiec jest wyższy niż 55 metrów. Terminem wieżowiec określa się budynek, który będzie się charakteryzował odpowiednio dużym stosunkiem wysokości do największego wymiaru w płaszczyźnie poziomej. Zatem wysokościowiec będzie wieżowcem pod warunkiem, że nie będzie miał zbyt dużej powierzchni zabudowy. Przedstawiony artykuł dotyczy doboru geotechnicznych metod rozpoznania podłoża wysokościowców, zwłaszcza tych najwyższych, jakie już istnieją, oraz tych, jakie będą wybudowane w Polsce w najbliższym czasie. Mowa zatem o budynkach, które mogą mieć kilkaset metrów wysokości.

W Polsce pierwszą niesakralną budowlą, która nieomalże spełniała dzisiejsze kryteria wysokościowca, był popularny budynek PASTy w Warszawie, wybudowany w centrum miasta, przy ulicy Zielnej, w latach

${ }^{凶}$ miroslaw_lipinski@sggw.pl 
1906-1908. W okresie międzywojennym wybudowano pojedyncze wysokościowce, a w czasach PRLu chociaż budowano budynki wyższe niż $55 \mathrm{~m}$, to jednak nie było ich wiele, a budowa niektórych ciągnęła się latami (np. tzw. błękitny wieżowiec w Warszawie). Wyjątkiem jest Pałac Kultury i Nauki w Warszawie (obecnie $237 \mathrm{~m}$ ), ale on ze względu na polityczną proweniencję powinien być traktowany jako wyjątek. Dopiero po 1989 roku, wraz ze zmianą ustroju, nastąpił istotny wzrost liczby budowanych wysokościowców.

Na rysunku 1 przedstawiono porównanie wysokości budynków realizowanych w Warszawie dla dwóch trzydziestoletnich okresów, tj. 1960-1989 (rys. 1a) oraz 1991-2020 (rys. 1b). W przypadku drugiego trzydziestolecia uwzględniono budynki, których realizacja już się rozpoczęła. Osoby, które pamiętają historię PRL, mogą łatwo zauważyć, że wykres na rysunku 1a można interpretować w kategoriach politycznych, natomiast histogramy na rysunku $1 \mathrm{~b}$ mogą wynikać jedynie $\mathrm{z}$ koniunktury gospodarczej.
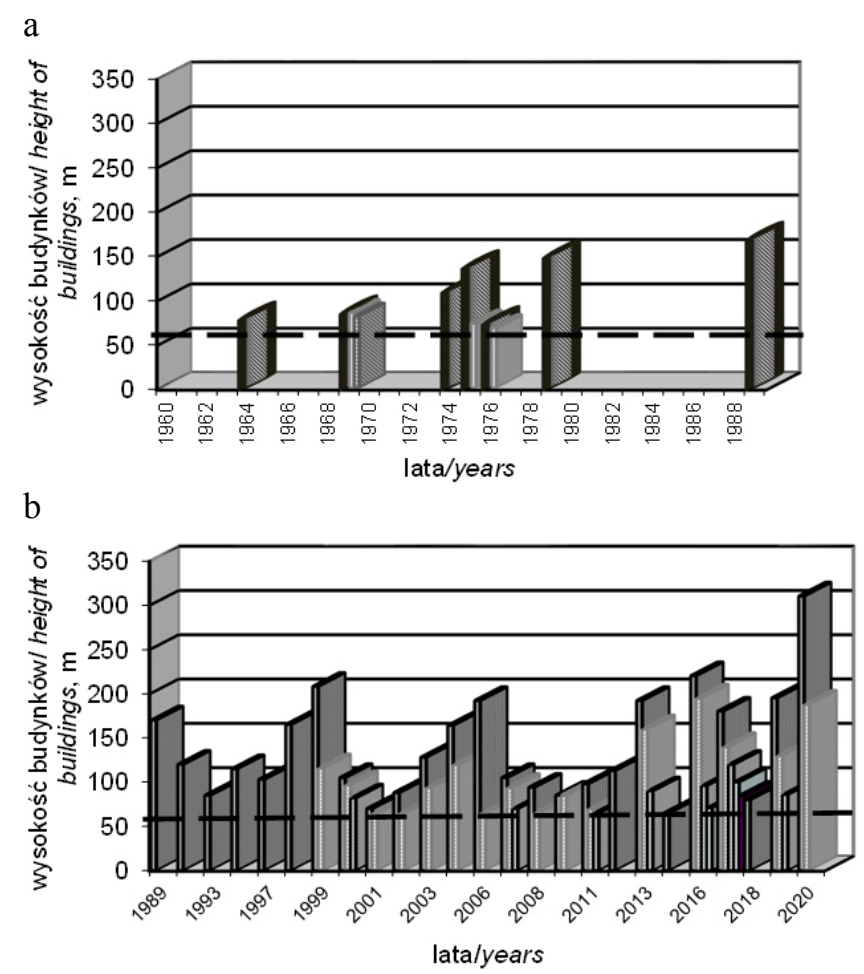

Rys. 1. Budowa wysokościowców w Warszawie w latach: a - 1960-1989, b-1991-2020

Fig. 1. Construction of high-rise buildings in Warsaw in periods: $a-1960-1989, b-1991-2020$

Budowa wysokiego budynku w centrum miasta to zagadnienie złożone, wymagające współpracy inżynierów $\mathrm{z}$ różnych branż. W odniesieniu do zagadnień geotechnicznych powszechnie akceptowany wśród projektantów jest pogląd, że stan graniczny użytkowalności w największym stopniu wpływa na projekt. Zatem zasadniczym problemem jest wyznaczenie parametrów stanu i sztywności. $\mathrm{Z}$ doświadczenia autorów wynika, że z punktu widzenia geologa i konstruktora, a w jeszcze większym stopniu architekta zagadnienie to nie wydaje się wykraczać poza standardowe rozpoznanie podłoża. Zrealizowane przykłady rozpoznania podłoża warszawskich wysokościowców jednoznacznie dowodzą, że tak nie jest. W artykule przedstawiono, na czym polega problem rozpoznania podłoża w przypadku wysokich budynków. Pokazano również na przykładach, na podstawie jakich rodzajów badań laboratoryjnych i terenowych można oszacować parametry potrzebne do prognozy zachowania się wysokich budynków. 


\section{METODY}

\section{Na czym polega problem doboru badań?}

W przypadku rozpoznania podłoża na potrzeby wysokich budynków istnieją dwa rodzaje problemów, które należy rozwiązać. Są to problemy komunikacyjno-decyzyjne oraz doboru właściwych metod określania parametrów geotechnicznych. Pierwszy rodzaj problemów wynika z faktu, że na etapie decyzji o rozpoznaniu podłoża nie wiadomo, kto będzie wykonywał obliczenia i w związku z tym nie jest jasne, jakie parametry będą potrzebne projektantowi. Ponadto inwestorzy często posługują się specyfikacjami badań przygotowanymi nawet przez osoby kompetentne (najczęściej z zagranicy), ale dla innych obiektów, a zatem nieuwzględniających warunków, jakie panują w podłożu, a także najczęściej niespełniających wymagań potrzebnych do wykonania obliczeń. Z kolei firmy, które wygrywają przetargi na wykonanie badań podłoża, często muszą podzlecać przeprowadzenie niektórych bardziej specjalistycznych badań ze specyfikacji, ponieważ będąc nastawione na badania standardowe, nie są w stanie ich zrealizować. Dzieje się tak dlatego, że do zarządzania realizacją budowy wysokościowca wynajmowani są przez inwestora menedżerowie, którzy rozliczani są głównie z ilości pieniędzy zaoszczędzonych podczas projektowania i realizacji budowy, a nie z dostosowania rozpoznania podłoża na potrzeby projektanta. A zatem najczęściej zdarza się tak, że ekonomista lub prawnik pośredniczy w rozmowach pomiędzy geologiem a konstruktorem, co jak łatwo przewidzieć - daje takie efekty jak dziecięca zabawa w głuchy telefon.

Drugi rodzaj problemów ma charakter merytoryczny, a jego związki z pierwszym rodzajem trudności polegają na niedostosowaniu rodzaju badań do warunków panujących w podłożu. Najczęściej planowane są otwory w celu rozpoznania budowy geologicznej podłoża oraz sondowania statyczne CPTu (rzadziej DMT). I tutaj najczęściej pojawia się pierwsze rozczarowanie. Zakres penetracji możliwy do zrealizowania najczęściej jest niewystarczający z punktu widzenia oczekiwanego rozpoznania. Możliwość wciśnięcia sondy kończy się na kilku metrach lub niewiele przekraczających $10 \mathrm{~m}$ głębokościach. Poniżej opory penetracji są tak duże, że penetrometr (niezależnie, czy montowany na samochodzie ciężarowym, czy na kotwionej przyczepie) nie jest w stanie zapewnić wystarczającej reakcji i jest podnoszony. Rozczarowanie jest jeszcze większe, gdy sondy statyczne są wyposażone w moduły sejsmiczne, ponieważ wspomniane maksymalne głębokości są zwykle mniejsze niż głębokość wykopu, z którego dna wykonywane są prace fundamentowe.

W tej sytuacji, gdy niemożliwe jest wciśnięcie sond statycznych lub wbicie sondy dynamicznej DPSH, należy rozważyć wykonanie badania sondą cylindryczną SPT, które jest wykonywane w dnie otworu. Takie rozwiązanie jest możliwe, ma jednakże zarówno zalety, jak i wady. Niewątpliwą jego zaletą jest możliwość wykonania sondowania praktycznie do dowolnej głębokości. Drugą, bardzo istotną przewagą tego sondowania jest coraz częstsze udokumentowane jego zastosowanie i korelacja z innymi wynikami badania, co istotnie rozszerza możliwości interpretacyjne. Przykładowo, istnieją korelacje wyników sondowań SPT z pomiarami prędkości fali poprzecznej. Należy jednakże pamiętać, że w przypadku zdecydowania się na ten rodzaj sondowania konieczne jest dokonanie korekty do liczby uderzeń $(N)$ potrzebnych na $0,3 \mathrm{~m}$ wpędu próbnika. Korekta powinna być wykonana ze względu na wartość składowej pionowej naprężenia na głębokości $\left(N_{1}\right)$, na jakiej wykonywane jest sondowanie, a także na ilość energii dostarczanej do cylindra podczas sondowania $(N)_{60}$ (rys. 2a). O ile nie powinno być problemu z korektą ze względu na naprężenie pionowe, to w przypadku korekty ze względu na energię należy przewidywać problemy. Standardowo zakłada się, że ilość energii dostarczanej do cylindra stanowi $60 \%$ energii potencjalnej wynikającej z masy obciążnika i wysokości jego spadania. W literaturze geotechnicznej (np. Cestari, 2012) można znaleźć wskazówki dla ustalenia poprawek uwzględniających rodzaj sondy, sposób zwalniania obciążenia, rodzaj i wymiary żerdzi itp., które pozwalają na oszacowanie ilości energii dostarczanej do cylindra. Biorąc jednakże pod uwagę różne konfiguracje sprzętu, jakie mogą się pojawić na miejscu budowy, ten rodzaj określenia poprawki nie jest dokładny. Poprawnym rozwiązaniem tego problemu jest pomiar energii dostarczanej do cylindra w trakcie każdego uderzenia. Niestety tego rodzaju pomiarów nie wykonuje się w Polsce standardowo. Polskie firmy oferujące wykonanie sondowań SPT nie oferują tego rodzaju 
a

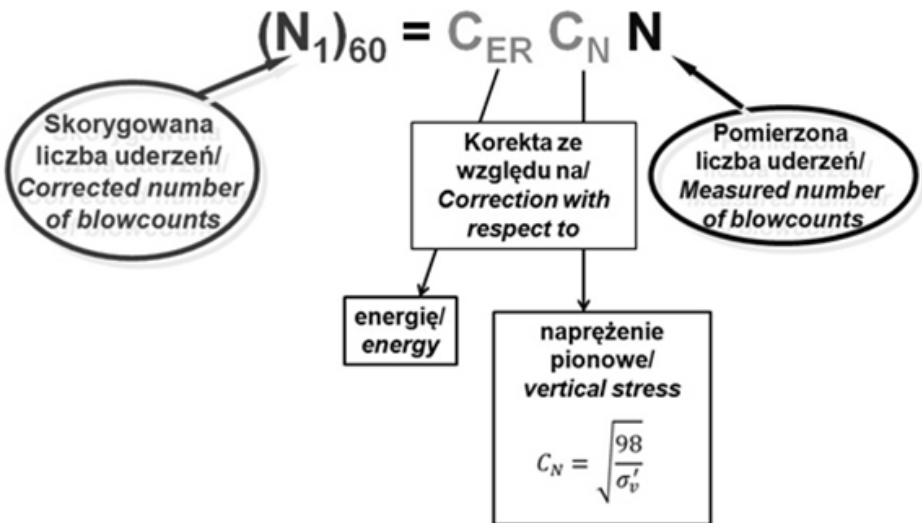

b

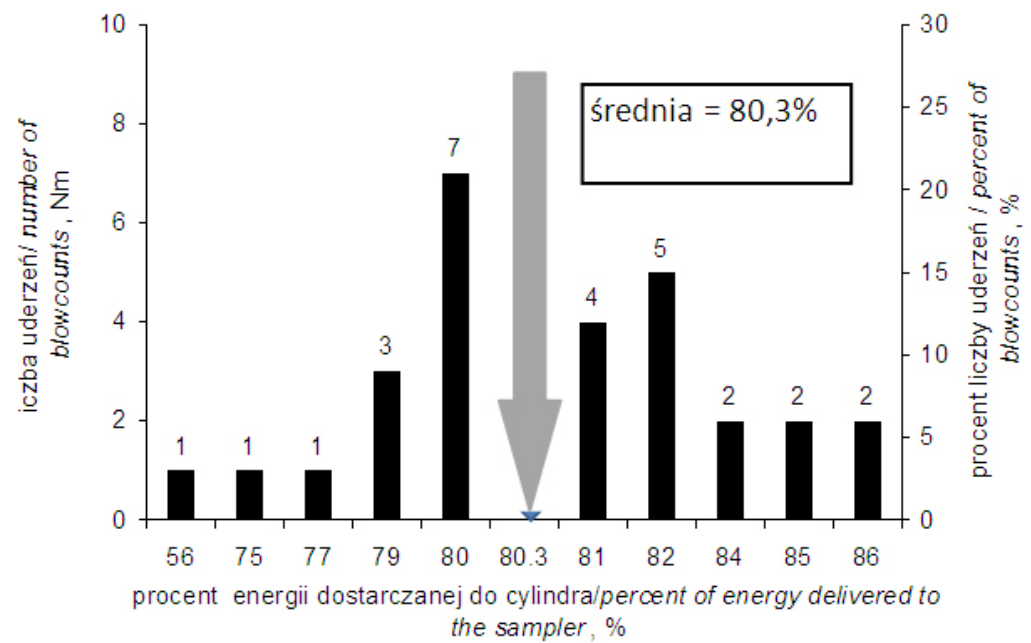

Rys. 2. Korekta pomierzonej liczby uderzeń w sondowaniu SPT (a) oraz pomierzona ilość energii dostarczonej do cylindra (b)

Fig. 2. Correction of SPT blow counts (a) and example of measured energy delivered to the sampler (b)

usługi. Nieliczne doświadczenia autorów z wykonywania tego rodzaju pomiarów w Polsce na pożyczonym (z zagranicy) sprzęcie dowodzą, że zakładana ilość energii wcale nie musi odpowiadać pomierzonej. Przykład histogramów energii pomierzonej podczas sondowania SPT, przedstawiony na rysunku $2 \mathrm{~b}$, wskazuje, że średnia ilość energii wynosi 80,3\%. Wynika to z czynników, które nie mogą być uwzględnione w poprawkach, tj. stanu dokręcenia żerdzi czy thumienia energii podczas uderzenia. A zatem nie dysponując sprzętem do pomiaru energii, nie jest możliwe wiarygodne określenie skorygowanej ilości energii podczas sondowania. W tej sytuacji istnieje potrzeba alternatywnych metod rozpoznania podłoża.

Analizę możliwości rozpoznania podłoża należy rozpatrywać pod kątem danych potrzebnych do prognozy deformacji podłoża, którą zwykle wykonuje się przy wykorzystaniu metody elementów skończonych, zakładając sprężysto-plastyczne zachowanie się gruntu. A zatem kluczowymi parametrami (oprócz parametrów wytrzymałościowych) są parametry stanu i sztywność materiału. W dalszej części artykułu metody rozpoznania podłoża będą omówione ze względu na te dwie grupy parametrów. 


\section{Pomiary prędkości fal akustycznych in situ}

W ostatnich latach daje się zauważyć znaczący rozwój technik i interpretacji pomiarów prędkości fal poprzecznych i podłużnych $\mathrm{w}$ gruncie $\mathrm{w}$ zastosowaniu do zagadnień geotechnicznych. Wynika to $\mathrm{z}$ nieinwazyjności tego rodzaju pomiaru, co pozwala na zwiększenie możliwości interpretacyjnych poprzez wykorzystanie teorii sprężystości. W geofizyce od dawna stosuje się metody sejsmiczne, jednakże w zastosowaniu geotechnicznym używane są inne nadajniki, odbiorniki, odległości i częstotliwości. Wynika to z większych wymagań w stosunku do dokładności otrzymywanych wyników. Podstawowe techniki otworowe, które mogą być zastosowane do rozpoznania podłoża pod wysokie budynki, to metody cross-hole i down-hole. Więcej informacji na temat sposobu wykonania badania oraz (co bardzo istotne) sposobu przygotowania i sprawdzenia otworów można znaleźć w pracach Lipińskiego $(2000,2013)$. Fakt wykonywania badania w otworach całkowicie likwiduje problem pomiaru na większych głębokościach, a dodatkowo przy małych odległościach pomiędzy otworami dokładność pomiarów jest dalece większa niż w sejsmicznych metodach bezotworowych.

Pierwszą grupę parametrów stanowią wielkości opisujące stan gruntu. W tym przypadku rozważane są nie tylko standardowe parametry normowe, jak stopień zagęszczenia dla gruntów niespoistych $\left(I_{D}\right)$ i wskaźnik konsystencji dla gruntów spoistych $\left(I_{C}\right)$. Ważny jest początkowy stan naprężenia, a zatem współczynnik parcia bocznego w spoczynku $\left(K_{0}\right)$. Dane te potrzebne są nie tylko do obliczeń, ale także do prawidłowego wykonania laboratoryjnych badań właściwości mechanicznych (najczęściej trójosiowych). A zatem rozpoznanie parametrów stanu można sprowadzić do wyznaczenia profili rozkładu wskaźnika porowatości $\left(e_{0}\right)$ i współczynnika parcia bocznego w spoczynku $\left(K_{0}\right)$.

Warto w tym miejscu zaznaczyć, że w Polsce w wyniku licznych zlodowaceń budowa geologiczna podłoża jest zwykle bardzo skomplikowana. Tak jest np. w Warszawie na terenie dzielnicy Śródmieście, gdzie obecnie istnieje i planuje się wybudować najwięcej wysokościowców. W takim stanie rzeczy standardowe podejście, polegające na wydzieleniu poszczególnych warstw i dla każdego rodzaju gruntu oddzielnie określenie parametrów stanu, jest bardzo utrudnione i zwykle nie uzyskuje się wiarygodnych danych. Stosując metody sejsmiczne, można obejść ten problem, wykorzystując teorię Biota dotyczącą propagacji fal sejsmicznych w porowatym ośrodku dwufazowym. Termin ośrodek dwufazowy odnosi się do wymogu pełnego wypełnienia porów gruntu płynem (zakłada się, że wodą). Warunek ten musi być bezwzględnie spełniony. Foti, Lai i Lancellotta (2002), wykorzystując teorię Biota, podali wzór na obliczenie porowatości na podstawie pomierzonych prędkości fali podłużnej i poprzecznej w następującej postaci:

$$
n=\frac{\rho_{s}-\left[\left(\rho_{s}\right)^{2}-\frac{4\left(\rho_{s}-\rho_{f}\right) K_{f}}{V_{p}^{2}-2\left(\frac{1-v_{s k}}{1-2 v_{s k}}\right) V_{s}^{2}}\right]^{0,5}}{2\left(\rho_{s}-\rho_{f}\right)}
$$

gdzie: $\rho_{s}-$ gęstość właściwa szkieletu gruntowego,

$\rho_{f}-$ gęstość właściwa cieczy wypełniającej pory,

$v_{s k}-$ współczynnik Poissona badanego gruntu,

$K_{f}-$ moduł odkształcenia objętościowego cieczy wypełniającej pory,

$V_{s}$ - prędkość fali poprzecznej,

$V_{p}-$ prędkość fali podłużnej.

Oprócz prędkości fal, które muszą być pomierzone, wartości parametrów występujących we wzorach mogą być dobrane na podstawie dostępnych danych i doświadczenia własnego. Warto zwrócić uwagę, że obliczona 
w ten sposób porowatość odnosi się do całego profilu, bez względu na rodzaj gruntu znajdującego się w poszczególnych warstwach wyróżnionych w przekroju.

Drugi parametr stanu, odnoszący się do stanu naprężenia, tj. współczynnik parcia bocznego w spoczynku $\left(K_{0}\right)$, można również oszacować na podstawie prędkości fal sejsmicznych. Bardziej skomplikowane podejście wykorzystuje pomiary prędkości fal poprzecznych pomierzone metodą cross-hole $\mathrm{w}$ dwóch polaryzacjach. To podejście wymaga bardzo precyzyjnych pomiarów i dodatkowych danych dotyczących anizotropii materiału. Więcej na ten temat, wraz z przykładami wyników badań, można znaleźć w pracy Lipińskiego (2013). Alternatywne podejście, rekomendowane do celów inżynierskich, polega na wykorzystaniu wyników pomiaru prędkości fal poprzecznych uzyskanych z metody cross-hole i down-hole. Wykorzystując inspiracje badaniami Tatsuoka, Jardine, Lo Presti, Di Benedetto i Kodaka (1997), dotyczącymi anizotropii sztywności gruntów niespoistych w zakresie małych odkształceń oraz doświadczenia firmy $\operatorname{GEOTEKO~}(2006,2013)$, autorzy proponują wyznaczenie współczynnika parcia bocznego w spoczynku $\left(K_{0}\right)$ na podstawie następującej formuły:

$$
K_{0}=\left(\frac{V_{S(H V)}}{V_{S(V H)}}\right)^{2}
$$

gdzie: $V_{s(H V)}$ - prędkość fali poprzecznej z metody cross-hole,

$V_{s(V H)}$ - prędkość fali poprzecznej z metody down-hole.

Analogicznie jak w przypadku porowatości, obliczone ze wzoru wartości parametru stanu odnoszą się do głębokości pomierzonych prędkości fal, bez względu na układ warstw i rodzaj gruntów zalegających w podłożu. Przykłady obliczonego w przedstawiony powyżej sposób rozkładu wskaźnika porowatości $\left(e_{0}\right)$ oraz współczynnika parcia bocznego w spoczynku $\left(K_{0}\right)$ dla podłoża jednego z najwyższych wysokościowców w Warszawie (Warsaw Spire o wysokości z iglicą $220 \mathrm{~m}$ ) przedstawiono na rysunku 3.
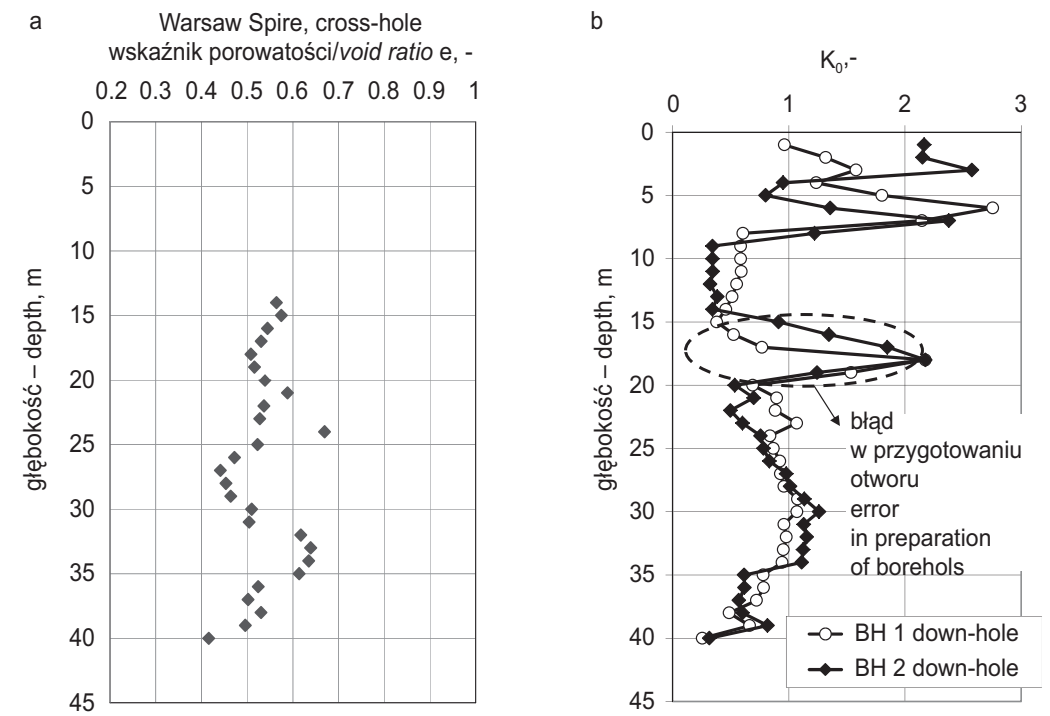

Rys. 3. Rozkład wskaźników porowatości (a) i współczynnika parcia bocznego w spoczynku $K_{0}$ (b) określony na podstawie prędkości fal sejsmicznych wyznaczonych z metody cross-hole i down-hole (dwie lokalizacje)

Fig. 3. Distribution of void ratio (a) and coefficient of earth pressure at rest $K_{0}$ (b) derived from seismic waves velocity measured during cross-hole and down-hole methods (two locations) 
Pomierzona prędkość fali porzecznej oraz powszechnie znane związki z liniowej teorii sprężystości pozwalają na wyznaczenie początkowego modułu odkształcenia $\left(E_{0}\right)$. Rozkład tego modułu dla podłoża budynku Warsaw Spire przedstawiono na rysunku 4. Przedstawione na wykresie wartości są wielokrotnie większe aniżeli wartości modułów podanych (nawet dla piasków) w normie PN-81/B-03020. Dotyczy to zarówno gruntów niespoistych, jak i spoistych. Pomimo że prezentowane wartości $E_{0}$ są większe niż sztywność operacyjna (czyli parametr charakterystyczny), to jednak redukcja nie jest duża. Obliczone wartości osiadania, zgodne z wynikami pomierzonymi (około $2-3 \mathrm{~cm}$ ), potwierdzają to jednoznacznie.

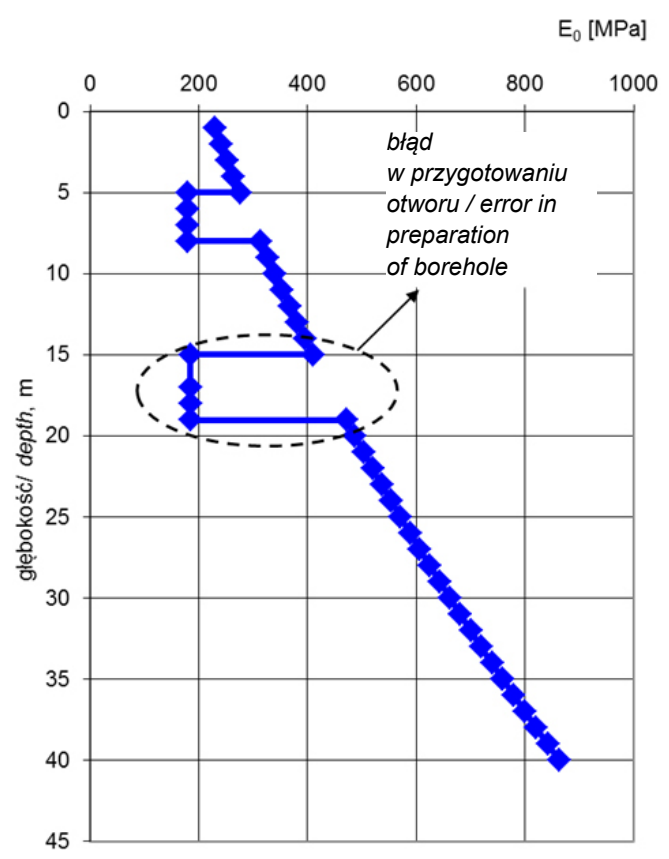

Rys. 4. Rozkład początkowego modułu odkształcenia $\left(E_{0}\right)$ określony na podstawie pomiarów prędkości fali poprzecznej dla podłoża budynku Warsaw Spire

Fig. 4. Initial deformation modulus $\left(E_{0}\right)$ distribution determined in foundation soil of Warsaw Spire high rise building on the basis of shear wave velocity measurement

\section{Badania laboratoryjne}

Jak przedstawiono we wcześniejszych rozdziałach artykułu, w przypadku doboru badań terenowych do rozpoznania podłoża wysokościowców najlepszym rozwiązaniem jest kombinacja badań cross-hole i down-hole. Jednakże rynek badań geotechnicznych w Polsce jest nadal (określając to eufemistycznie) na etapie wczesnokapitalistycznym. Oznacza to, że inwestor chce oszczędzać na wszystkim na czym się da, a na badaniach (których nie widać) jest najłatwiej. W związku z tym zdarza się, że badania sejsmiczne nie zostają zlecone. W tej sytuacji należy szukać rozwiązań alternatywnych. Pierwszym krokiem jest skorzystanie z już istniejących formuł, które pozwoliłyby na oszacowanie sztywności na podstawie rodzaju gruntu i podstawowych cech fizycznych, które można określić na reprezentatywnej próbce gruntu o nienaruszonej strukturze (NNS). Takie warunki spełnia propozycja formuły podanej przez Lipińskiego i Tymińskiego (2011), pozwalająca określić początkowy moduł sprężystości poprzecznej $\left(G_{0}\right)$ na podstawie wskaźnika plastyczności $\left(I_{P}\right)$ i wskaźnika porowatości $(e)$ oraz średniego naprężenia efektywnego $\left(p^{\prime}\right)$. Postać formuły jest następująca:

$$
G_{0}=G_{50}+41 \cdot I p^{-1.57}\left(p^{\prime}-50\right)
$$


Wartości naprężenia należy wstawiać w kPa natomiast wskaźnik plastyczności w \%. Wynik otrzymywany jest w MPa. Sposób korzystania ze wzoru przedstawiono na rysunku 5. Analizując wszystkie rodzaje mineralnych gruntów spoistych występujących na terenie Polski o wskaźnikach $I_{p}$ z zakresu od 8 do $90 \%$, Autorzy zauważyli, że zmianę sztywności początkowej na jednostkę przyrostu naprężenia średniego można opisać zależnością funkcyjną, w której zmiennymi są $I_{p}$ i $p$ ' (rys. 5a). Aby określić wartość offsetową $G_{50}$, należy posłużyć się wykresem z rysunku 5b, gdzie na podstawie wskaźnika porowatości i trzech klas wskaźnika plastyczności można określić podzieloną przez $50 \mathrm{kPa}$ wartość offsetową początkowego modułu sprężystości porzecznej.

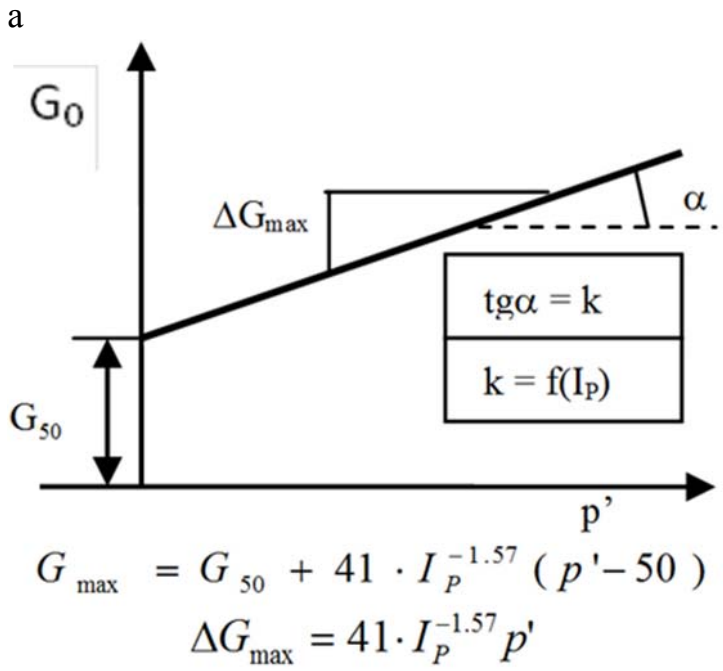

b

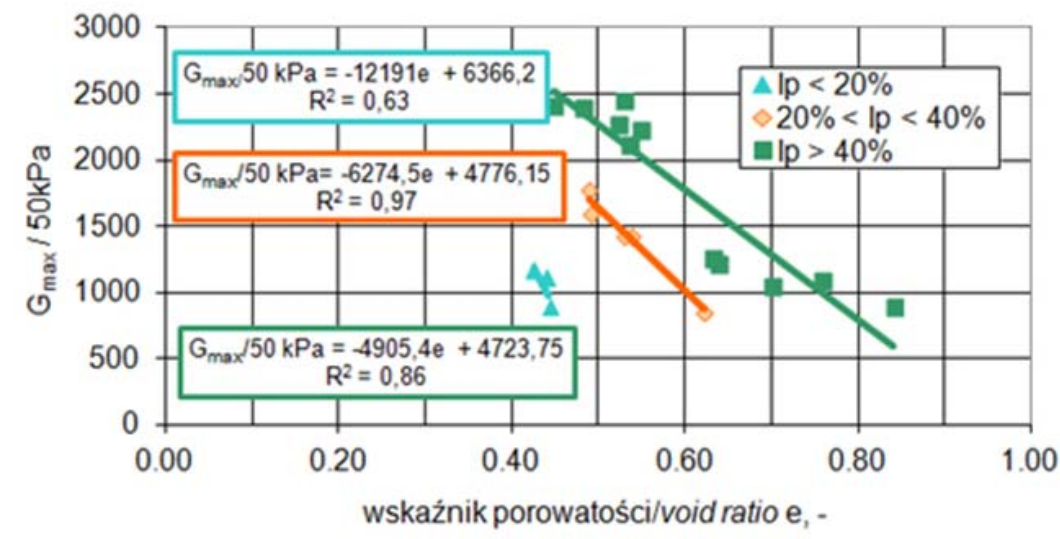

Rys. 5. Formuła do wyznaczania sztywności początkowej w mocnych gruntach spoistych

Fig. 5. The formula for evaluation of initial shear modulus in stiff cohesive soils

Odmienna sytuacja występuje w przypadku gruntów niespoistych, które zwykle występują pod głębokimi fundamentami wysokościowców. Wprawdzie w zachodniej literaturze geotechnicznej istnieje wiele formuł opracowanych na podstawie badań laboratoryjnych, pozwalających wyznaczyć sztywność początkową w różnych piaskach, to jednak konieczna jest znajomość wskaźnika porowatości, co w gruncie niespoistym jest zawsze problemem, ponieważ trudno jest pobrać próbkę o nienaruszonej strukturze. Ponadto w formułach na sztywność 
początkową występują składowe pionowa i pozioma naprężenia średniego. O ile składowa pionowa nie stanowi większego problemu, to jednak składowa pozioma zwykle nie jest znana. Zatem najlepszym rozwiązaniem jest określenie prędkości fali poprzecznej bezpośrednio w terenie na podstawie metod sejsmicznych.

Drugi problem, jaki należy rozwiązać, to określenie sztywności charakterystycznej, czyli dla zakresu odkształcenia, jaki przewidywany jest po obciążeniu podłoża. Formuły, które można znaleźć w literaturze, redukują sztywność w stosunku do jej wartości początkowej, zatem konieczna jest znajomość $G_{0}$. Jedynie pojedyncze propozycje określone dla jednego rodzaju gruntu nie stawiają tego warunku. Taką propozycją jest formuła zaproponowana przez Lipińskiego (2013), która została opracowana dla drobnego piasku zagęszczonego i uzależnia moduł odkształcenia $(E)$ od naprężenia średniego $\left(p^{\prime}\right)$ i zakresu odkształcenia $(\varepsilon)$. Dla zagęszczonego piasku drobnego do wskaźnika porowatości 0,62 formuła przybiera następującą postać:

$$
E=\frac{12,3+35,4\left(p^{\prime}-0,1\right)}{\varepsilon^{0.58}}
$$

Wartości naprężenia należy wstawiać w MPa, natomiast odkształcenie w \%. Sposób wyprowadzenia wzoru, którego podstawą były serie badań trójosiowych z wewnątrzkomorowym pomiarem przemieszczeń, można znaleźć w pracy Lipińskiego (2013).

Rozkład wartości modułu odkształcenia obliczony z tego wzoru przedstawiono na rysunku 6 . Z wykresu tego wynika, że w roboczym zakresie odkształceń wartości modułów pochodzących z badań mogą być nawet sześciokrotnie większe aniżeli te sugerowane w normie PN-81/B-03020. Wielkość osiadania wysokich budynków, gdzie obliczenia wykonywano na podstawie modułów określonych z badań, nie pozostawiają żadnych wątpliwości, które wartości lepiej opisują rzeczywistość.

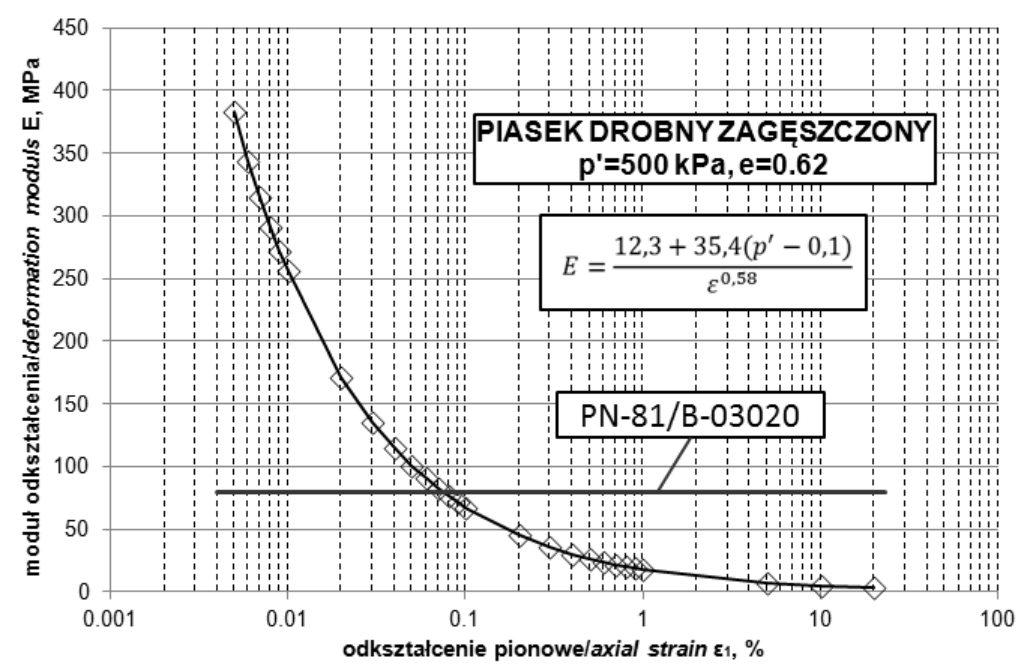

Rys. 6. Formuła do wyznaczania sztywności w stanach przedzniszczeniowych w zagęszczonych piaskach drobnych

Fig. 6. The formula for evaluation of secant deformation modulus in dense fine sand

W przypadku niemożności skorzystania z gotowych wzorów istnieje konieczność przeprowadzenia badań na materiale niespoistym pobranym z podłoża. Ponieważ nie wydaje się, aby z bardzo zagęszczonego, niespoistego gruntu można było pobrać w Polsce próbki o nienaruszonej strukturze, w związku z tym taki materiał 
należy zrekonstruować bezpośrednio w komorze aparatu trójosiowego, stosując tzw. metodę niedogęszczania w warstwach (ang. moist tamping by undercompaction) zaproponowaną przez Ladda (1978). Wykonując serie badań trójosiowych z wewnątrzkomorowym pomiarem przemieszczeń dla różnych początkowych wskaźników porowatości oraz różnych wartości naprężenia efektywnego podczas ścinania, można otrzymać zależność modułu odkształcenia od naprężenia średniego dla różnych początkowych stanów zagęszczenia, tak jak to przedstawiono na rysunku 7. Przedstawiony wykres dotyczy gruntu podłoża budynku Złota $44 \mathrm{w}$ Warszawie $(192 \mathrm{~m}$ wysokości), w którym zastosowano takie podejście. Dzięki współpracy firm GEOTEKO i ARUP powstało wiele takich wykresów dla różnych rodzajów piasków i różnych zakresów odkształcenia. Dzięki temu prognoza osiadania budynku zgadza się z wartościami obserwowanymi na podstawie monitoringu.

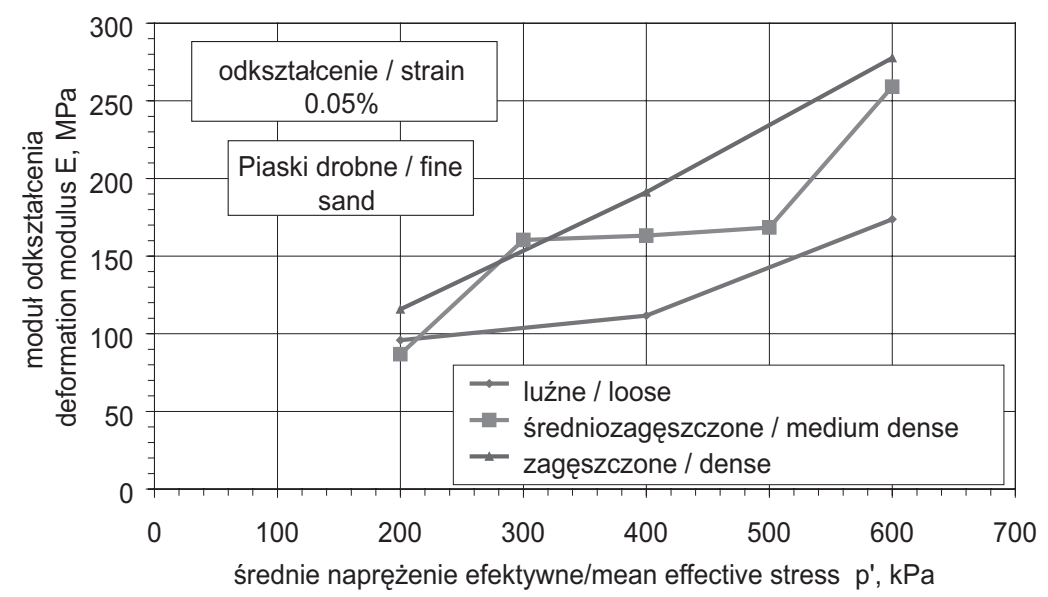

Rys. 7. Przykład zmiany modułów odkształcenia $\left(E_{0,05}\right)$ w zależności od średniego naprężenia efektywnego dla piasków z podłoża wysokościowca ul. Złota 44

Fig. 7. Example of deformation moduli $\mathrm{E}_{0.05}$ against mean effective stress for sands of foundation under Złota 44 high rise building

\section{PODSUMOWANIE}

Dobór badań na potrzeby rozpoznania podłoża bardzo wysokich budynków różni się istotnie od zakresu badań zdecydowanej większości dokumentacji, wykonywanych dla obiektów budownictwa lądowego, wodnego lub komunikacyjnego. Skomplikowane warunki geologiczne, konieczność rozpoznania do dużych głębokości i grunty w stanie zagęszczonym lub półzwartym to wszystko powoduje, że standardowe metody sondowań nie sprawdzają się w takich warunkach. Ponadto ograniczenia przy projektowaniu fundamentu wysokiego budynku wynikają ze stanu użytkowalności, co wymaga określenia sztywności w zakresie małych i średnich odkształceń.

W artykule przedstawiono uzasadnienie merytoryczne dla powyższych uwarunkowań oraz zaproponowano podejście opierające się na wybranych badaniach terenowych i laboratoryjnych, których wyniki w pełni pozwalają na wykonanie prognozy przemieszczeń zgodnej z wynikami z pomiarów w terenie po realizacji budowy. Podejście to zostało zweryfikowane na przykładzie trzech wysokościowców wybudowanych w ostatnich latach w Warszawie. W artykule przedstawiono przykłady interpretacji badań sejsmicznych cross-hole i down-hole, pozwalające na określenie parametrów stanu i sztywności początkowej. Podejście to pozwala na uzyskanie wskaźnika porowatości $\left(e_{0}\right)$, współczynnika parcia bocznego w spoczynku $\left(K_{0}\right)$ oraz modułu początkowego 
$\left(E_{0}\right)$ z dokładnością daleko większą niż w przypadku innych metod. Przedstawiono formuły empiryczne, które mogą być wykorzystane do oszacowania sztywności początkowej gruntów spoistych jedynie na podstawie podstawowych cech fizycznych oraz podano przykład formuły pozwalającej na wyznaczenie siecznego modułu $(E)$ dla dowolnego stanu naprężenia i odkształcenia. Na koniec przedstawiono sposób postępowania w przypadku konieczności określenia wartości charakterystycznej modułu odkształcenia (siecznego) w przypadku występowania kilku rodzajów gruntu.

\title{
PIŚMIENNICTWO
}

Cestari, F. (2012). In situ geotechnical tests. Patron editore Quarto inferior, Bologna.

Foti, S., Lai, C. G. i Lancellotta, R. (2002). Porosity of fluid-saturated porous media from measured seismic wave velocities. Gèotechnique, 52 (5), 359-373.

GEOTEKO (2006). Dokumentacja geotechniczna dla potrzeb projektu budowlanego budynku mieszkalno-ustugowego „,City Center” Warszawa, ul. Złota 44/46. Opracowanie: M. J. Lipiński z zespołem.

GEOTEKO (2013). Evaluation of soil stiffness distribution under foundation of Warsaw Spire building A. Geoteko Report prepared by: M. J. Lipiński, W. Tymiński \& T. Kiełczewski.

Ladd, R. S. (1978). Preparing Test Specimens Using Under-Compaction. Geotechnical Testing Journal, ASTM, 1 (1), $16-23$.

Lipiński, M. J. (2000). Undrained Response of Cohesionless Soils to Monotonic Loadings. (PhD thesis). Faculty of Hydro and Environmental Engineering. Gdansk: Technical University.

Lipiński, M. J. (2013). Kryteria wyznaczania parametrów geotechnicznych. Warszawa: Wydawnictwo SGGW.

Lipiński, M. J. i Tymiński, W. (2011). Evaluation of initial stiffness of natural overconsolidated cohesive soils. XV European Conference on Soil Mechanics and Geotechnical Engineering (ISSMGE), Athens, 209-214.

PN-81/B-03020. Grunty budowlane. Posadowienie bezpośrednie budowli. Obliczenia statyczne i projektowanie

Tatsuoka, F., Jardine, R. J., Lo Presti, D. C. F., Di Benedetto, H. i Kodaka, T. (1997). Characterising the pre-failure deformation properties of Geomaterials. Theme lecture for Plenary Session No 1. Proc. 14th International Conference on Soil Mechanics and Foundation Engineering, Hamburg, 4, 2129-2164.

\section{SELECTION OF GEOTECHNICAL METHODS FOR IDENTIFICATION OF SOIL CONDITIONS UNDER HIGH RISE BUILDINGS}

\begin{abstract}
In case of high rise building foundation soil, unlike in other objects a special selection of geotechnical methods is required for site characterization. The paper reveals limitations of standard methods applicability to identification of soil conditions. A ready to use formulae for stiff cohesive and dense cohesionless soils were presented which can be used as the first step in evaluation of soil stiffness at the stage of foundation design. Taking advantage of examples of recently constructed high rise buildings in Warsaw an approach to identification of initial state and stiffness parameters determination was presented.
\end{abstract}

Key words: high rise buildings, site characterization, selection of parameters determination method, seismic waves velocity, state parameter, soil stiffness 